\title{
Geopolymer Mortar with Fly Ash
}

\author{
Saloma $^{1,{ }^{*}}$, Anis Saggaff ${ }^{1}$, Hanafiah ${ }^{1}$, and Annisa Mawarni ${ }^{1}$ \\ ${ }^{1}$ Sriwijaya University, Jl. Palembang-Prabumulih, KM.32, Inderalaya, Ogan Ilir, South Sumatra, \\ 30662, Indonesia.
}

\begin{abstract}
The cement industry accounts for about $7 \%$ of all $\mathrm{CO}_{2}$ emissions caused by humans. Therefore, it is necessary to find another material in order to support sustainable material. An alternative way is replacing cement material with alternative material as fly ash. Fly ash as binder need to be added alkaline activator in the form of sodium silicate $\left(\mathrm{Na}_{2} \mathrm{SiO}_{3}\right)$ or potassium silicate $\left(\mathrm{K}_{2} \mathrm{SiO}_{3}\right)$ and sodium hydroxide $(\mathrm{NaOH})$ or potassium hydroxide $(\mathrm{KOH})$. The purpose of this research is to analyze the effect of activator liquid concentration on geopolymer mortar properties and to know the value of compressive strength. Molarity variation of $\mathrm{NaOH}$ are $8,12,14$, and $16 \mathrm{M}$ with ratio of $\mathrm{Na}_{2} \mathrm{SiO}_{3} / \mathrm{NaOH}=$ 1.0. Ratio of sand/fly ash $=2.75$ and ratio of activator/fly ash $=0.8$. The cube-shaped specimen $50 \times 50 \times 50 \mathrm{~mm}$ is cured by steam curing with a temperature of $60^{\circ} \mathrm{C}$ for 48 hours. The experimental result of fresh mortar reported that the molarity of $\mathrm{NaOH}$ affect the slump flow and setting time, higher of $\mathrm{NaOH}$ produces the smaller value of slump and the faster time of setting. The experimental of density results reported that the increase of specific gravity when the molarity of $\mathrm{NaOH}$ increased. The experimental results of the compressive strength are showed that the maximum compressive strength of geopolymer mortar $14 \mathrm{M}$ is $10.06 \mathrm{MPa}$ and the lowest compressive strength produced by geopolymer mortar $8 \mathrm{M}$ is 3.95 $\mathrm{MPa}$. Testing the compressive strength of geopolymer mortar $16 \mathrm{M}$ produces compressive strength lower than $14 \mathrm{M}$ geopolymer mortar is 9.16 $\mathrm{MPa}$.
\end{abstract}

\section{Introduction}

Nowadays, construction world has been shown a fair progress with the development of materials technology. One of the construction progress that had been developed was mortar. Mortar is the material used for building construction that is a mixture of fine aggregate, a binder, and water. Generally, the binder uses in mortar is cement.

Fly ash is wasting material which is produced by the power plant and it can be used as an alternative replacement of cement material. To be a binder, fly ash should be added with an alkaline activator as a catalyst of fly ash. Alkaline activator that commonly used in geopolymerization is a combination of sodium silicate $\left(\mathrm{Na}_{2} \mathrm{SiO}_{3}\right)$ or potassium silicate $\left(\mathrm{K}_{2} \mathrm{SiO}_{3}\right)$ and sodium hydroxide $(\mathrm{NaOH})$ or potassium hydroxide $(\mathrm{KOH})$ [1]. The ratio of $\mathrm{K}_{2} \mathrm{SiO}_{3}$ to $\mathrm{KOH}$ in order to produce high strength of geopolymer mortar is in the range 0.8

\footnotetext{
* Corresponding author: saloma_571@yahoo.co.id
} 
to 1.5 [2]. The molarity of $\mathrm{NaOH}$ or $\mathrm{KOH}$ that can be used as an activator is in the range 8 $\mathrm{M}$ to $16 \mathrm{M}[3,4]$.

Based on the previous research, the writer has conducted a manufacture of geopolymer mortar with alkaline activator sodium silicate $\left(\mathrm{Na}_{2} \mathrm{SiO}_{3}\right)$ and sodium hydroxide $(\mathrm{NaOH})$ as the catalyst of fly ash. This research is also conducted to determine the properties of geopolymer mortar.

\section{Material}

This research was conducted in the Laboratory of Materials and Concrete, Civil Engineering Department, Faculty of Engineering, University of Sriwijaya. The specimen of this research was a cube-shaped size $50 \times 50 \times 50 \mathrm{~mm}$ with steam curing at a temperature of $60^{\circ} \mathrm{C}$ for 48 hours. The variation of molarity, $\mathrm{NaOH}$, which is used were $8,12,14$, and $16 \mathrm{M}$ with a ratio of $\mathrm{Na}_{2} \mathrm{SiO}_{3} / \mathrm{NaOH}=1.0$. The ratio of sand $/$ fly ash $=2.75$ and the ratio of activator / fly ash $=0.8$.

The material used in this research consists of fly ash where it came from power plant Tanjung Enim, South Sumatera, fine aggregate from Tanjung Raja, sodium hydroxide $(\mathrm{NaOH}) 98 \%$ purity flake, sodium silicate $\left(\mathrm{Na}_{2} \mathrm{SiO}_{3}\right)$ with $58 \%$ of solid gel purity, and water. Material testing of this research are the physical properties of fine aggregate test and chemical analysis test of fly ash. The testing of chemical analysis was conducted in the Laboratory of PT.Semen Baturaja Palembang. The chemical composition of the chemical analysis of fly ash can be seen in Table 1. From the result, it showed that the compound of fly ash was classified into class $\mathrm{F}$ containing of $\mathrm{SiO}_{2}+\mathrm{Al}_{2} \mathrm{O}_{3}+\mathrm{Fe}_{2} \mathrm{O}_{3}=87.54 \%$ and the $\mathrm{CaO}$ content $=3.75 \%$.

Table 1. The chemical composition of the fly ashes.

\begin{tabular}{|l|c|c|c|c|c|c|c|c|}
\hline $\begin{array}{l}\text { Chemical } \\
\text { composition }\end{array}$ & $\mathrm{SiO}_{2}$ & $\mathrm{Al}_{2} \mathrm{O}_{3}$ & $\mathrm{Fe}_{2} \mathrm{O}_{3}$ & $\mathrm{CaO}$ & $\mathrm{MgO}$ & $\mathrm{SO}_{3}$ & LOI & IR \\
\hline Percentage & 82.04 & 3.70 & 1.80 & 3.75 & 0.01 & 0.08 & 3.50 & 78.97 \\
\hline
\end{tabular}

Before producing mortar, first, it needed an activator solvent of $\mathrm{NaOH}$ and $\mathrm{Na}_{2} \mathrm{SiO}_{3}$ based on molarity needed. The solvent is made manually using a measuring cup and spatula. Then the solvent was allowed to stand for about 24 hours to achieve a homogenous solvent. The producing of fresh mortar is done by mixing fly ash and sand for 3 minutes. Then the activator solvent is added into the mixture of fly ash-sand and it is mixed for 10 minutes. Next, fresh mortar is filled into the mold in size $50 \times 50 \times 50 \mathrm{~mm}$ which has been smeared with lubricant oil. The filling process is done in two stages. Each stage of filling, $25 \mathrm{~mm}$ of concrete mix is filled then it's compacted. Then fresh mortar that has been moulded is cured with steam curing at temperature $60^{\circ} \mathrm{C}$ for 48 hours.

\section{Laboratory Test}

This research conducted in Laboratory of Concrete and Material, Civil Engineering Faculty of Engineering, Universitas Sriwijaya. The standard for mortar mixed material refers to American Standart Testing and Material (ASTM C109). The experiment that has been conducted were workability, setting time, density and compressive strength test. The $\mathrm{NaOH}$ 's molarity variation are $8,12,14$ and $16 \mathrm{M}$ with a ratio of $\mathrm{Na}_{2} \mathrm{SiO}_{3} / \mathrm{NaOH}=1.0$. Ratio of sand/fly ash $=2.75$ and ratio of activator/fly ash $=0.8$. The cube-shaped specimen $50 \times 50 \times 50 \mathrm{~mm}$ is cured by steam curing with a temperature of $60^{\circ} \mathrm{C}$ for 48 hours. The 
workability test conducted by test the flow table to know the diameter distribution. While the compressive strength test conducted using a $50 \times 50 \times 50 \mathrm{~mm}$ cube-sized material for 3 , $7,14,21$ and 28 days period.

\section{Result and Analysis}

\subsection{Slump Flow}

The result of slump flow test has a different value for each composition based on the molarity of $\mathrm{NaOH}$. The result of slump flow can be seen in Figure 1. Based on the result of slump flow test it can be concluded that the greater molarity value of $\mathrm{NaOH}$, the smaller slump value will be resulted. It causes due to the influence of molarity on the viscosity of activator solvent can influence the workability of the mixture.

\subsection{Setting time}

The result of setting with any variations of $\mathrm{NaOH}$ molarity can be seen in Figure 2. The result of setting time showed that the molarity of $\mathrm{NaOH}$ is greatly affected the setting time of geopolymer mortar. The greater value of $\mathrm{NaOH}$ molarity, the faster setting time is needed and vice versa the smaller value of $\mathrm{NaOH}$ molarity, the longer setting time is needed.

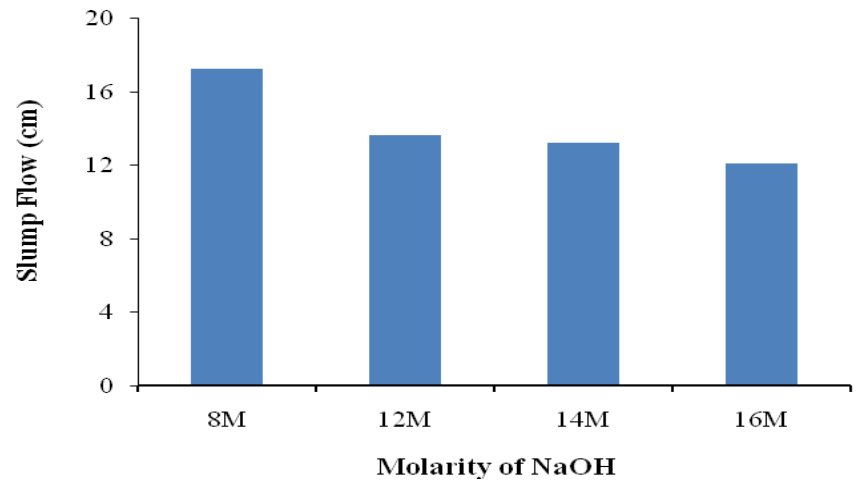

Fig. 1. The result of slump flow.

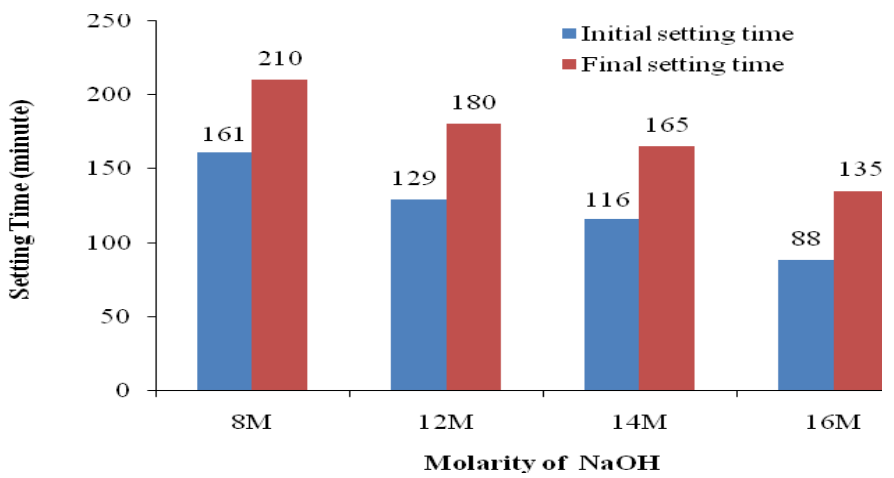

Fig. 2. The result of setting time. 


\subsection{Density}

The test of density is tested before the test of compressive strength conducted. The data is obtained by weighing the weight of the specimen. The result of mortar geopolymer density can be seen in Figure 3. Based on the test, it can be explained that the greater value of $\mathrm{NaOH}$ molarity, the greater value of density is obtained. Mortar with the lowest molarity has more porous so it has a lower density than mortar with higher molarity. The result of density geopolymer mortar has a lower density than cement mortar is between range 2.17 to $2.19 \mathrm{gr} / \mathrm{cm}^{3}[5,6]$.

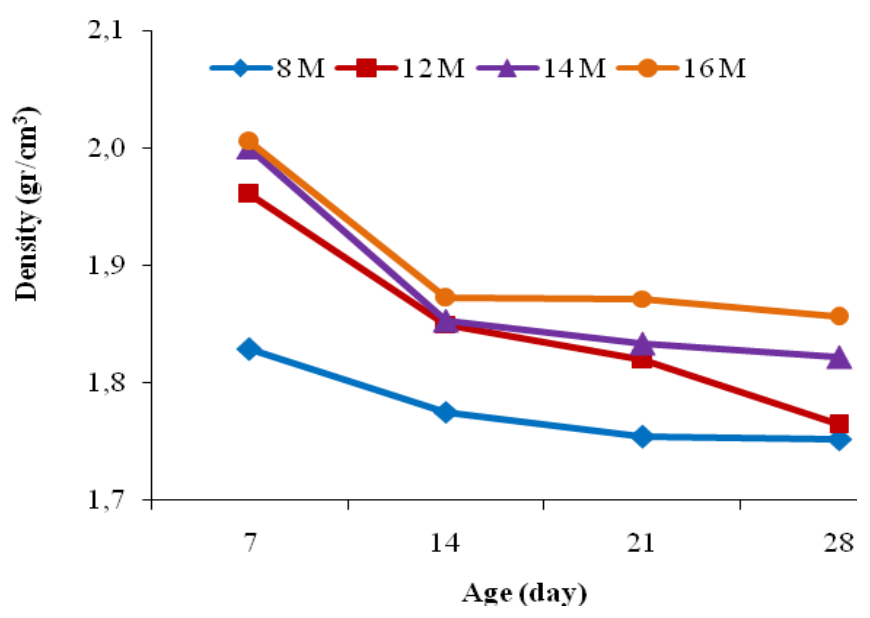

Fig. 3. The result tests of density.

\subsection{Compressive Strength}

The result of testing on each variation of $\mathrm{NaOH}$ molarity for aged 7, 14, 21, and 28 days can be seen in Figure 4. The minimum result of mortar compressive strength for aged 28 days is obtained by $8 \mathrm{M}$ of mortar geopolymer with $3.95 \mathrm{MPa}$. The maximum compressive strength for 28 days is produced by mortar $14 \mathrm{M}$ in the amount of $10.06 \mathrm{MPa}$. The compressive strength of geopolymer mortar $16 \mathrm{M}$ resulting lower than geopolymer mortar $\mathrm{NaOH} 14 \mathrm{M}$.

The maximum compressive strength which is produced by geopolymer mortar $14 \mathrm{M}$ is lower than the compressive strength of cement mortar type S according to ASTM C132903. The compressive strength of cement mortar type $\mathrm{S}$ which is required by ASTM C 1329-03 for 7 days and 28 days are $9.0 \mathrm{MPa}$ and $14.5 \mathrm{MPa}$. The difference of compressive strength between geopolymer mortar and cement mortar is $30,62 \%$. 


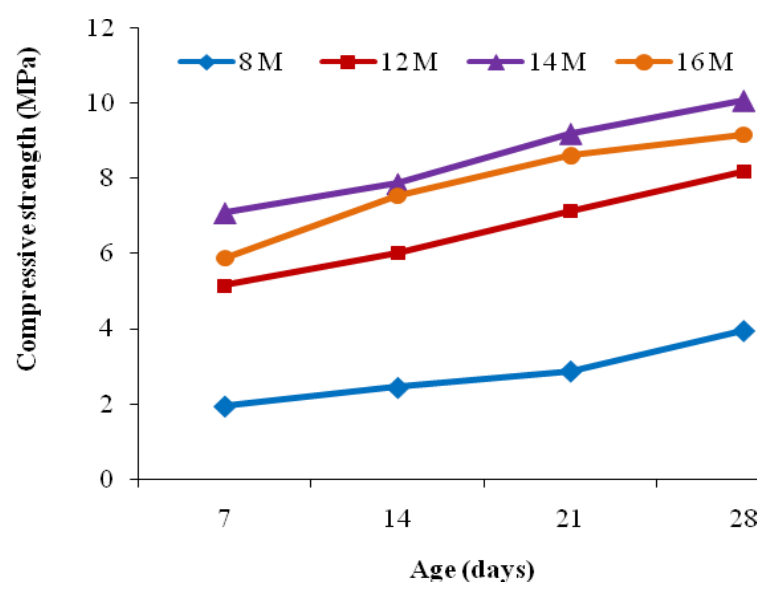

Fig. 4. The result of mortar compressive strength.

\subsection{Regression Analysis of Mortar Compressive Strength}

Regression analysis used the maximum result of compressive strength generated by geopolymer mortar $14 \mathrm{M}$. Regression analysis of the compressive strength of geopolymer mortar for various age testing refers to the equations recommended by ACI 209.2R-08. Regression analysis of the compressive strength of geopolymer mortar based on the compressive strength of mortar ACI 209.2R-08 can be seen in Figure 5.

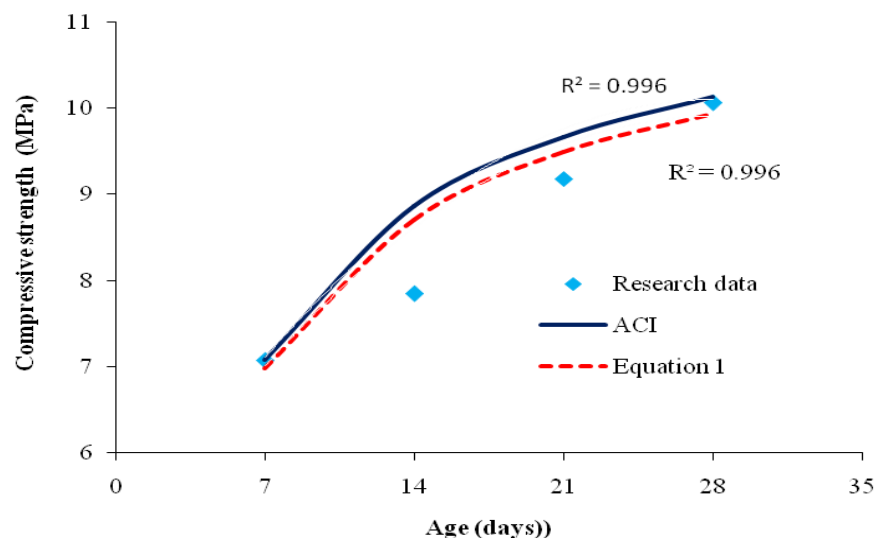

Fig. 5. Regression analysis of mortar compressive test.

The function used to determine the compressive strength for various age of this research can be seen in Equation 1.

$$
f_{c t}^{\prime}=\left[\frac{\mathrm{t}}{4,35+0,88 . \mathrm{t}}\right] \mathrm{f}_{\mathrm{c} 2}{ }^{\prime} 28
$$

The coefficient of determination $\mathrm{R}^{2}=0.9966$. The value of $\mathrm{R}^{2}$ which is close to 1 indicates that the regression analysis approach is good at accuracy. 


\section{Conclusion}

The conclusion that can be drawn based on the results of research on the effects $\mathrm{Na}_{2} \mathrm{SiO}_{3}$ and $\mathrm{NaOH}$ on the properties of geopolymer mortar are as follows

- The greater the molarity of $\mathrm{NaOH}$, the smaller value of slump flow obtained, thereby it reduces the workability of the mixture. The smaller value of molarity $\mathrm{NaOH}$, the greater value of slump flow obtained that improve the workability of the mixture.

- The greater the molarity of $\mathrm{NaOH}$, the faster setting time needed.

- The greater the molarity of $\mathrm{NaOH}$, the greater the density of geopolymer mortar obtained

- The result of compressive strength showed that the maximum value is obtained on geopolymer mortar $14 \mathrm{M}$ in the amount of $10.06 \mathrm{MPa}$ and the minimum value is obtained on geopolymer mortar $8 \mathrm{M}$ which is equal to $3.95 \mathrm{MPa}$. In mortar mixture of $16 \mathrm{M}$, it decreases the compressive strength equal to 9.16 MPa. Based on these result, it can be concluded that the optimum mixture to get the maximum strength is used $\mathrm{NaOH} 14 \mathrm{M}$.

- The result of regression analysis is based on ACI 209.2R-08 can be drawn that the coefficient of determination $\mathrm{R}^{2}=0.9966$. Based on $\mathrm{R}^{2}$ it can be concluded that the testing of geopolymer mortar is fairly reached good accuracy.

- The result of compressive strength of geopolymer mortar is lower than cement mortar type S according to ASTM C 1329-03.

This work was financially supported by the DIPA Sriwijaya University 2015.

\section{References}

1. D. Hardjito, Journal-American Concrete Institute, 101(6), 467 (2004)

2. D. Hardjito, S.S. Fung, Modern Applied Science, 4(1), 44 (2010)

3. D. Hardjito, S.S.E. Asia, Modern Applied Science, 2, 3 (2008)

4. D. Hardjito, M. Tsen, The 3rd International Conference ACF/VCA, 2003, 144 (2008) 